\title{
Evaluation of Heavy Metals Contamination from Environment to Food Matrix by TXRF: The Case of Rice and Rice Husk
}

\author{
Fabjola Bilo, Marco Lodolo, Laura Borgese, Alberto Bosio, Laura Benassi, \\ Laura Eleonora Depero, and Elza Bontempi \\ Chemistry for Technologies Laboratory, Department of Mechanical and Industrial Engineering, University of Brescia, \\ Via Branze 38, 25123 Brescia, Italy
}

Correspondence should be addressed to Elza Bontempi; elza.bontempi@unibs.it

Received 4 December 2014; Revised 2 March 2015; Accepted 3 March 2015

Academic Editor: Javier Hernandez-Borges

Copyright (C) 2015 Fabjola Bilo et al. This is an open access article distributed under the Creative Commons Attribution License, which permits unrestricted use, distribution, and reproduction in any medium, provided the original work is properly cited.

This paper is devoted to the chemical analysis of contaminated soils of India and the rice grown in the same area. Total reflection $\mathrm{X}$-ray fluorescence spectroscopy is a well-established technique for elemental chemical analysis of environmental samples, and it can be a useful tool to assess food safety. Metals uptake in rice crop grown in soils from different areas was studied. In this work soil, rice husk and rice samples were analyzed after complete solubilization of samples by microwave acid digestion. Heavy metals concentration detected in rice samples decreases in the following order: $\mathrm{Mn}>\mathrm{Zn}>\mathrm{Cu}>\mathrm{Ni}>\mathrm{Pb}>\mathrm{Cr}$. The metal content in rice husk was higher than in rice. This study suggests, for the first time, a possible role of heavy metals filter played by rice husk. The knowledge of metals sequestration capability of rice husk may promote some new management practices for rice cultivation to preserve it from pollution.

\section{Introduction}

Heavy-metal pollution of soil affects the quality of the environment leading to serious consequences. Heavy metals group includes $\mathrm{Ag}, \mathrm{Ba}, \mathrm{Cd}, \mathrm{Co}, \mathrm{Cr}, \mathrm{Mn}, \mathrm{Hg}, \mathrm{Mo}, \mathrm{Ni}, \mathrm{Pb}, \mathrm{Cu}, \mathrm{Sn}$, $\mathrm{Tl}, \mathrm{V}, \mathrm{Zn}$, and some metalloids such as $\mathrm{As}, \mathrm{Sb}, \mathrm{Bi}$, and $\mathrm{Se}$. Arsenic, for example, is often considered as a heavy metal due to the similarity of its chemical properties and behavior with the other heavy metals. Heavy metals accumulation in soil, and in the environment in general, may be related to the phenomenon of bioaccumulation ability of living organisms, that is, increasing the concentration at human organism due to industrial activities and the food chain. The main sources of heavy-metal pollution in soil are irrigation, especially with sewage; solid-waste disposal, for example, sludge and compost refuse; the use of pesticides and fertilizers; and atmospheric deposition [1].

Plants acquire the necessary nutrients, such as $\mathrm{N}, \mathrm{P}$, and $\mathrm{K}$, from the environment. However, they may also accumulate unnecessary and toxic metals, such as $\mathrm{Pb}$ and $\mathrm{Cd}$. Several plants have the ability to accumulate high metal concentrations [2]. Many studies have reported data for the transfer of heavy metals from soil to plants and vegetables through roots and shoot [3]. Therefore, toxic metals such as As, $\mathrm{Cd}$, and $\mathrm{Pb}$ can be taken up from cereal crops and transferred to their grains [4]. Toxic metals may be classified according to their capability of being transferred from soil to plants in mobile metals, such as $\mathrm{Cd}$, and poorly mobile metals, such as $\mathrm{Pb}$. This property may affect their bioaccumulation in plants [5].

Rice is one of the most important and widespread cereals in the world. It is the staff of life for 3 billion people, mainly in Asia [6], contributing over $70 \%$ of the energy and $50 \%$ of the protein provided by their daily food intake. In the last report of EU Commission, India was presented as the first country for rice production with 19\% of export. India is followed by Cambodia and Thailand. United States and Vietnam are the countries with less amount of imported rice [7]. About $80 \%$ of the rice production of Europe takes place in Italy and Spain, with a further $12 \%$ in Greece and Portugal.

On this basis the presence of toxic heavy metals in rice, which may raise the metal daily intake, should be strongly avoided in order to prevent negative effects on human health. The following elements are considered macronutrients in rice and their content is usually in some \%: $\mathrm{P}, \mathrm{S}, \mathrm{K}, \mathrm{Ca}$, and $\mathrm{Mg}$. 
Other elements, like $\mathrm{Mn}, \mathrm{Fe}, \mathrm{Cu}, \mathrm{Zn}, \mathrm{Se}$, and $\mathrm{Ni}$, are classified as micronutrients and they are present in lower amount, while $\mathrm{As}, \mathrm{Cr}, \mathrm{Pb}$, and $\mathrm{Cd}$ are undesirable elements because of their toxic effects even in very low quantity. As a consequence, it is crucially necessary to reduce possible accumulation effects in rice grains from the environment for safe food production. Great efforts are necessary to remediate polluted sites. Other approaches could be developed to reduce metals accumulation in edible parts of plants. For instance, favorable agronomic practices and chemical regulators may decrease plant heavy metals uptake. In this context it is important to identify which parts of the plant accumulate more toxic substances.

Rice husk $(\mathrm{RH})$ is the external protecting covering of each rice grain. The chemical composition of $\mathrm{RH}$ varies from sample to sample depending on rice variety, climate, and origin. Organic compounds and water are the main components of $\mathrm{RH}$ (about 74\%), followed by amorphous silica (between 15 and 22\%) and other inorganic compounds (about 4\%) such as $\mathrm{Al}_{2} \mathrm{O}_{3}, \mathrm{Fe}_{2} \mathrm{O}_{3}, \mathrm{CaO}$, and $\mathrm{MgO}$ [8]. Omatola and Onojah [9] reported the following list of elements detected by $\mathrm{X}$ ray fluorescence (XRF) in $\mathrm{RH}: \mathrm{K}, \mathrm{Ca}, \mathrm{Cr}, \mathrm{Mn}, \mathrm{Fe}, \mathrm{Ni}, \mathrm{Cu}$, $\mathrm{Zn}, \mathrm{Sr}, \mathrm{Br}, \mathrm{I}$, As, and $\mathrm{Cl}$. These elements, owing to their low concentrations, are considered as impurities. Sun and Gong reported that the main application of $\mathrm{RH}[10]$ is the production of thermal energy, due to its high calorific value, about $13607 \mathrm{~kJ} / \mathrm{kg}$. Several other destinations of RH were reported, such as livestock for the cattle, agricultural fertilizer, ingredient for substrates in floriculture and horticulture, and simple fertilizer for plants. RH was also used for the production of biodegradable pots, instead of using oil.

It is also known that the produced byproduct of rice husk is called rice husk ash (RHA). RHA is widely used by the steel industry in the production of high quality flat steel for automotive body panels [11]. Owing to its insulating properties, RHA has been used in the manufacture of refractory bricks, which are exposed to extreme temperatures in furnaces, such as the blast furnaces employed for producing molten iron, and in the production of cement clinker. The Indian Space Research Organization has successfully developed the technology for producing high purity precipitated silica from RHA, which has a potential use in the computer industry $[12,13]$. American and Brazilian scientists also developed new ways to extract and purify silicon from RHA to use it in semiconductor manufacture. Other uses have been explored. In the frame of the COSMOS-RICE project, RHA is employed as metals stabilizer for municipal solid waste incineration fly ash treatment $[14,15]$.

It is very interesting to verify the higher capability of heavy accumulation by $\mathrm{RH}$ with respect to rice. This can play a fundamental role in the management of rice cultivation.

Elemental chemical analysis of rice is usually performed by normative techniques such as FAAS [16]. In this study we used total reflection X-ray fluorescence (TXRF) to analyze the chemical composition of rice, $\mathrm{RH}$, and soils of two different areas of India. The aim was the evaluation of metal uptake from soil to rice and the investigation of possible sources of environmental pollution in the studied areas. Moreover this work aims to highlight the possible role of $\mathrm{RH}$ in preserving rice from bioaccumulation of heavy metals.
TABLE 1: Type of samples and their corresponding numbers sampled from the studied areas.

\begin{tabular}{lcc}
\hline City & Samples & Number of samples \\
\hline Raipur & Soil & \\
Raipur & A & 5 \\
Raipur & B & 5 \\
Raipur & Rice husk (RH) & 5 \\
Raipur & Rice & 5 \\
Korba & Soil & 5 \\
Korba & Rice husk (RH) & 5 \\
Korba & Rice & 5 \\
\hline
\end{tabular}

\section{Materials and Methods}

2.1. Study Areas. Elemental chemical analysis of soils coming from the central-east area of India, where soil contains high concentration of heavy metals, was performed. The state of Chhattisgarh (India) is rich in minerals such as iron, limestone, dolomite, coal, bauxite, garnet, quartz, marble, alexandrite, and diamonds. Because of the huge production of rice, Chhattisgarh district nickname is "rice bowl of Central India." Industrial activities in this area increased a lot in the last years. In fact, the construction of new coal-fired power plants has increased up to $50 \%$ the production of ashes, which exposes the human and the environment to high pollution risks. Therefore, Raipur and Korba were chosen as the target cities of this study. Raipur is located at $21^{\circ} 13^{\prime} 60 \mathrm{~N}$ and $81^{\circ} 37^{\prime} 60$ $\mathrm{E}$, and hundreds varieties of rice grow. Different studies have already confirmed the presence of heavy metals in soils from this area, demonstrating a degradation of the environmental quality [17-19]. Meanwhile, Korba is located at $22^{\circ} 21^{\prime} 0 \mathrm{~N}$ and $82^{\circ} 40^{\prime} 60 \mathrm{E}$ and, as well as Raipur, it is also a "victim" of the industrial growth, especially of cement industry. Soil and rice samples from each city region were collected in 5 different areas. Samples in Raipur were collected in duplicate to check the homogeneity of its composition. The two samples, named as A and B in Table 1, were collected in the same area at a distance less than $1 \mathrm{~km}$ from each other.

2.2. Samples Preparation Procedure. Soil samples were homogenized through a mortar and dried for $90 \mathrm{~min}$ at $90^{\circ} \mathrm{C}$. Samples were weighed before and after this process in order to determine their humidity. Rice samples were transported from India as they were collected. Rice grains were inside their husk. The separation of each rice grain from its outer shell (husk) was carried out manually in the first step of sample preparation. Some differences were noticed at a glance. Rice samples had different husk colors, from green to yellow, and crop dimensions.

2.3. Digestion of Samples. About $0.5 \mathrm{~g}$ soil sample was added to $9 \mathrm{~mL}$ of nitric acid 65\% (Fluka), $3 \mathrm{~mL}$ of hydrofluoric acid (Fluka), and $2 \mathrm{~mL}$ of hydrochloric acid 37\% (Fluka) in Teflon vessels. HF was necessary to perform total solubilization of soil, probably due to the high content of silicates. This procedure was performed according to US-EPA 3050B method 


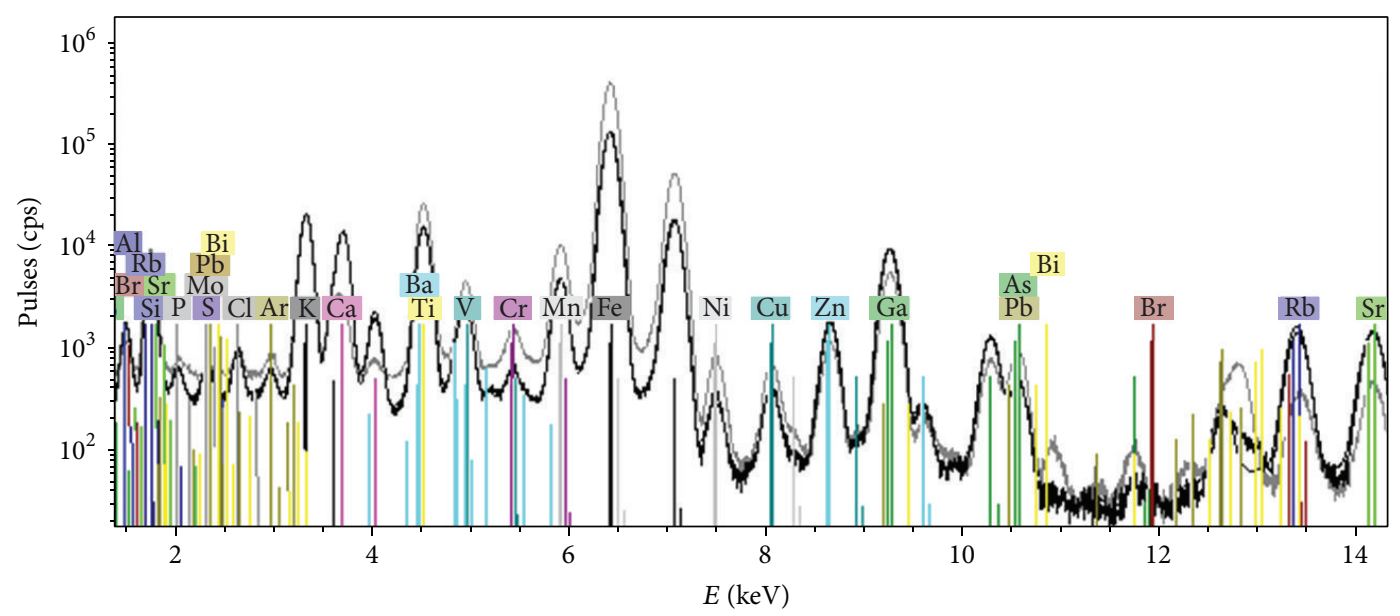

FIgURE 1: TXRF spectra of soil samples from Korba (black) and Raipur (grey).

[20]. Smaller quantities of RH and rice samples were used for digestion. About $0.30 \mathrm{~g}$ of rice and rice husk was weighed, transferred inside the vessel, and mixed with $10 \mathrm{~mL}$ of nitric acid 65\% (Fluka). A magnetic shaker was inserted in each vessel and then the vessel was closed with a cap provided with a hole to allow the leakage of gases formed during the digestion. A CEM microwave digestion device was used to digest the samples at $200^{\circ} \mathrm{C}$ and 400 Psi. After complete sample solubilization, the solutions were transferred to 25 and $10 \mathrm{~mL}$ volumetric flasks, respectively, for soil and rice/RH and filled with MilliQ water to the exact volume.

2.4. TXRF Analysis of Soils, Rice Husk, and Rice Samples. Chemical analysis of the solutions, obtained by digestion, was performed by means of TXRF spectroscopy. Quantitative analysis was performed by the internal standard addition procedure [21], using Ga as internal standard element, because it was not present in all the original samples. $10 \mu \mathrm{L}$ of Ga $(1 \mathrm{~g} / \mathrm{L})$ was added to $990 \mu \mathrm{L}$ of soil samples in order to obtain a final $\mathrm{Ga}$ concentration of $10 \mathrm{mg} / \mathrm{L}$. Ga concentration in rice and $\mathrm{RH}$ solutions was $1 \mathrm{mg} / \mathrm{L} .10 \mu \mathrm{L}$ of each sample solution was deposited on a three-quartz glass sample carrier, cleaned and siliconized, and then dried on a hot plate at $50^{\circ} \mathrm{C}$. TXRF measurements were performed by Bruker S2 Picofox, equipped with Mo tube, operating at $50 \mathrm{kV}$ and $750 \mu \mathrm{A}$, and Silicon-Drift Detector. Live time for each measurement was 600 seconds.

\section{Results and Discussion}

3.1. TXRF Analysis of Soils. Humidity in Raipur soils was higher than in Korba samples. It ranges from 1.4 to $6.7 \%$, while in Korba soils humidity was in the interval from 1.7 to $2.9 \%$.

TXRF spectra of soil samples from Korba and Raipur are shown in Figure 1. Signals of Al, K, Ca, Ti, V, Cr, Mn, Fe, $\mathrm{Ni}, \mathrm{Cu}, \mathrm{Zn}, \mathrm{As}, \mathrm{Rb}, \mathrm{Ba}, \mathrm{Pb}$, and $\mathrm{Sr}$ are clearly identified in all the samples of both cities region. Bi was present only in the soils from Raipur, suggesting possible anthropogenic causes.
Regarding the nonmetals, signals of $\mathrm{S}, \mathrm{Cl}$, and $\mathrm{Br}$ were always identified.

TXRF measurement was performed in air; for this reason it is not possible to give an accurate estimation of the content of lighter elements such as $\mathrm{Al}, \mathrm{P}$, and $\mathrm{S}$. Their concentration may be underestimated and higher standard deviations may occur (about $20 \%$ in the case of $\mathrm{Al}$ ). The content of $\mathrm{Fe}$ is higher compared to the other elements. For this reason, fitting of TXRF spectra was performed considering the pile up peak of $\mathrm{Fe} \mathrm{K} \alpha$. However, as it was demonstrated in a recent publication, TXRF is a successful technique to perform quantitative analysis of soils [22]. Background levels were kept to a minimum with the use of quartz sample carriers, reducing at minimum their contact time with $\mathrm{HF}$.

Results of quantitative analysis of soil samples are reported in Table 2. Heavy metals content is higher in Raipur soil samples compared with Korba samples. Almost all the elements concentrations are 4-5 times higher in Raipur than in Korba. Relative standard deviation (RSD) is used to evaluate the precision of the measurements. RSD for most of the elements $(\mathrm{Mn}, \mathrm{Fe}, \mathrm{Ni}, \mathrm{Cu}$, and $\mathrm{Zn})$ is in the range from 1 to 6.4\%. Slightly higher RSD values are observed for V, $9.4 \%$, and for $\mathrm{Ba}$, from 6.5 to $24.6 \%$, due to the reasons already discussed [22]. The highest RSD values are observed for Bi probably due to its low concentration, which is near the lowest limit of detection (LLD).

Descriptive statistics of elemental content in soil samples is reported in Table 3. Concentration of Bi is significantly lower compared to other elements in soils. Mn is the element with the widest range of concentrations and the largest differences in the two studies areas. $\mathrm{Zn}$ concentration is almost the same in both cities, while $\mathrm{Cr}$ and $\mathrm{Pb}$ are significantly higher in all the Raipur samples, highlighting the possible adverse effects of the metallurgy industry in Raipur. The data of soils collected in the same area of Raipur, in two different points, do not show any significant difference. This result figures out a homogeneous distribution of metals in the studied regions.

A comparison of our results with the guidelines and limits proposed for the determination of heavy metals pollution 


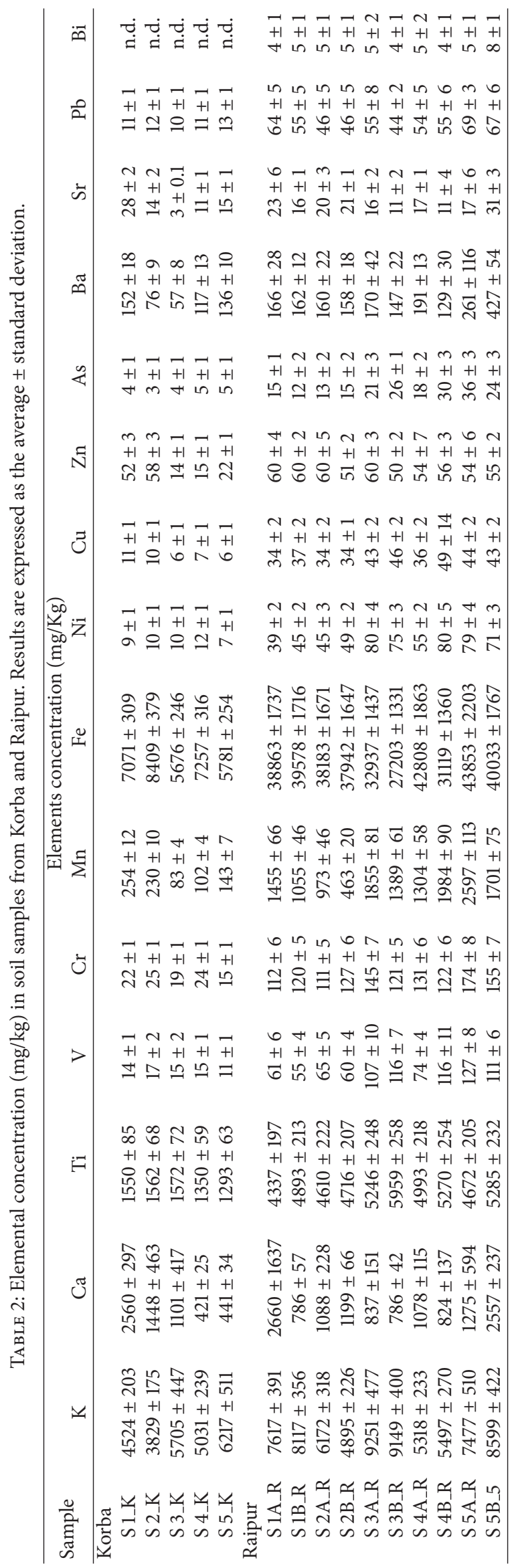


TABLE 3: Descriptive statistics results of elemental chemical analysis for Korba and Raipur soils.

\begin{tabular}{ccccccccccccccccc}
\hline & $\mathrm{K}$ & $\mathrm{Ca}$ & $\mathrm{Ti}$ & $\mathrm{V}$ & $\mathrm{Cr}$ & $\mathrm{Mn}$ & $\mathrm{Fe}$ & $\mathrm{Ni}$ & $\mathrm{Cu}$ & $\mathrm{Zn}$ & $\mathrm{As}$ & $\mathrm{Ba}$ & $\mathrm{Rb}$ & $\mathrm{Sr}$ & $\mathrm{Pb}$ & $\mathrm{Bi}$ \\
\hline Korba & & & & & & & & & & & & & & & & \\
Mean & 5061.10 & 1195.82 & 1465.22 & 14.38 & 20.78 & 162.39 & 6838.82 & 9.54 & 7.96 & 32.20 & 4.20 & 107.51 & 23.62 & 14.24 & 11.35 & n.d. \\
SD & 942.97 & 880.66 & 133.32 & 2.29 & 4.10 & 76.01 & 1136.39 & 1.90 & 2.29 & 21.11 & 0.64 & 39.98 & 7.20 & 8.98 & 1.20 & n.d. \\
Min & 3829.12 & 420.76 & 1292.66 & 11.08 & 14.56 & 82.90 & 5676.19 & 6.54 & 5.95 & 14.15 & 3.38 & 56.99 & 13.81 & 3.16 & 9.85 & n.d. \\
Max & 6216.60 & 2559.93 & 1571.93 & 17.32 & 24.68 & 253.70 & 8409.31 & 11.62 & 10.84 & 58.18 & 4.86 & 171.60 & 30.73 & 27.82 & 12.80 & n.d. \\
Raipur & & & & & & & & & & & & & & & \\
Mean & 7209.17 & 1309.09 & 4988.11 & 89.34 & 131.88 & 1477.54 & 37201.98 & 61.84 & 39.59 & 55.86 & 20.96 & 197.05 & 26.24 & 18.45 & 55.45 & 5.11 \\
SD & 1628.34 & 707.36 & 471.33 & 28.31 & 20.11 & 596.58 & 5189.52 & 16.60 & 5.91 & 3.86 & 8.05 & 88.00 & 16.64 & 6.32 & 8.94 & 1.18 \\
Min & 4895.48 & 785.77 & 4336.85 & 55.44 & 111.48 & 462.53 & 27202.51 & 39.34 & 31.09 & 50.03 & 11.90 & 129.43 & 10.23 & 10.76 & 43.55 & 3.83 \\
Max & 9251.30 & 3659.98 & 5958.69 & 126.84 & 173.61 & 2579.07 & 43354.00 & 79.93 & 48.51 & 60.11 & 35.68 & 427.57 & 71.32 & 32.75 & 69.21 & 8.15 \\
\hline
\end{tabular}

[23] indicates that all the soil samples of Korba are not contaminated, while soils from Raipur are contaminated by $\mathrm{Ni}, \mathrm{Cu}, \mathrm{Cr}, \mathrm{As}$, and $\mathrm{Ba}$.

A more detailed comparison of our data with those obtained in other studies of soil contamination in the same area reveals a good agreement. The comparison with data reported by Kabata Pendias for uncontaminated soils $(\mathrm{Cr}$ $0.4-29 \mathrm{mg} / \mathrm{kg}$, Mn $25-8000 \mathrm{mg} / \mathrm{kg}$, Ni 3-150 mg/kg, Cu 0.5$135 \mathrm{mg} / \mathrm{kg}$, Zn 1-750 mg/kg, and $\mathrm{Pb} 0.6-63 \mathrm{mg} / \mathrm{kg}$ ) [24] suggests that $\mathrm{Cr}$ and $\mathrm{Pb}$ contamination is present in Raipur. More recent studies by Srinivasa Gowd et al. [25] and Patel et al. [26] reported higher content of $\mathrm{Pb}, \mathrm{Zn}$, and $\mathrm{Cr}$. Thus, only contamination by $\mathrm{Cr}$ would be present. However, it should be considered that $\mathrm{Pb}, \mathrm{Zn}$, and $\mathrm{Cr}$ concentration increased easily during the industrial activity, particularly in the mining areas. So the increasing in metal concentration in these soils may be a consequence of anthropogenic influence.

Statistical analysis was used to evaluate the correlation of the elements present in soil. Cluster analysis was used to highlight the differences between soils from Korba and Raipur. Hierarchical division was performed using the Ward method, which is based on the analysis of variances instead of distances. The varimax rotation with Kaiser normalization method was used for factor analysis. By extracting the eigenvalues, the number of significant factors was determined. Data treatment was performed using the JMP 10 software. Results of cluster analysis are reported in Figure 2. The dendrogram clearly points out the division of the samples in two clusters corresponding to the different sampled areas of Korba and Raipur. Considering that the two studied cities belong to the same region of India, and supposing the same crustal composition, this result suggests a different degree of pollution.

Results of factor analysis show that the three eigenvalues explain $90,18 \%$ of the variance. Therefore, they were selected for further factor analysis. The loadings of elements with respect to each one of the three identified factors are reported in Table 4. All the elements with high loadings for the same factor may have a common origin in soils. The first factor is responsible for $56.3 \%$ of the total variance and it includes $\mathrm{K}$, $\mathrm{Ti}, \mathrm{V}, \mathrm{Cr}, \mathrm{Mn}, \mathrm{Fe}, \mathrm{Ni}, \mathrm{Cu}, \mathrm{Zn}, \mathrm{As}, \mathrm{Pb}$, and Bi. Considering the nature of these elements and their simultaneous presence this suggests their anthropogenic origin. The second factor

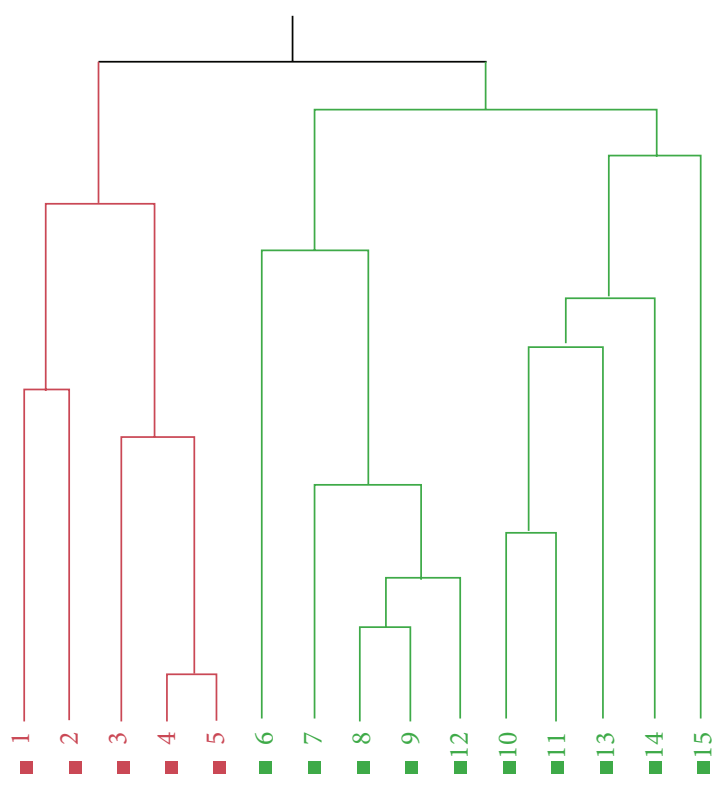

Figure 2: Dendrogram of cluster analysis for Korba (red) and Raipur (green) samples.

accounts for $17.09 \%$ of the total variance and it includes $\mathrm{Ca}$ and $\mathrm{Sr}$. $\mathrm{Ca}$ and $\mathrm{Sr}$ are included in the list of the eight most abundant rock forming elements of biosphere, which may be added to the soil from wind dispersion of dust from mine tailing and wastes tips $[27,28]$. The third principal component represented $16.79 \%$ of the total variance and it includes $\mathrm{Al}, \mathrm{Rb}$, and $\mathrm{Ba}$. The presence of $\mathrm{Al}$ would suggest a crustal origin. Indeed, $\mathrm{Al}$ acts as a natural marker element, while its anthropogenic origin is still unknown. $\mathrm{Al}$ is a conservative element and is contained in aluminosilicates as is reported by Vodyanitskii [29]. However, the crustal origin of $\mathrm{Rb}$ and $\mathrm{Ba}$ is not assessed.

3.2. TXRF Analysis of Rice and Rice Husk. TXRF spectra of rice and rice husk are shown in Figure 3. Signals of $\mathrm{Mg}, \mathrm{Al}$, $\mathrm{P}, \mathrm{S}, \mathrm{Cl}, \mathrm{K}, \mathrm{Ca}, \mathrm{Ti}, \mathrm{Cr}, \mathrm{Mn}, \mathrm{Fe}, \mathrm{Ni}, \mathrm{Cu}, \mathrm{Zn}, \mathrm{Ba}, \mathrm{Rb}, \mathrm{Pb}, \mathrm{Br}$, and $\mathrm{Sr}$ are identified in both rice and RH samples. After spectra deconvolution, concentration of each was determined except 


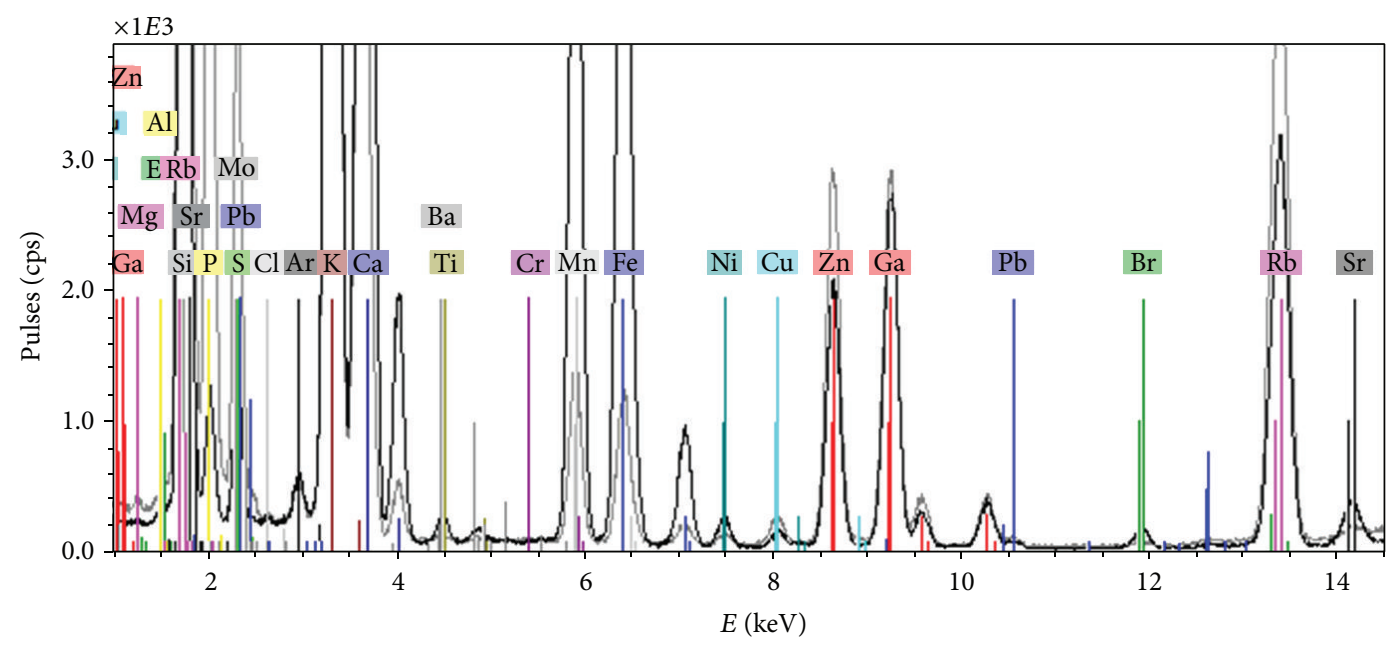

FIgURE 3: Spectra of rice husk (black) and rice (gray) sample 2 from Korba measured by S2 Picofox.

TABLE 4: Rotated component matrix for soil samples.

(a)

\begin{tabular}{lccc}
\hline Variables & \multicolumn{3}{c}{ Rotated factor } \\
\hline $\mathrm{Al}$ & 1 & 2 & 3 \\
$\mathrm{~K}$ & 0.4877 & 0.3792 & 0.7279 \\
$\mathrm{Ca}$ & 0.5859 & -0.0676 & 0.5477 \\
$\mathrm{Ti}$ & 0.0419 & 0.9249 & 0.1358 \\
$\mathrm{~V}$ & 0.9527 & 0.1259 & 0.0972 \\
$\mathrm{Cr}$ & 0.9167 & 0.0068 & 0.3339 \\
$\mathrm{Mn}$ & 0.9421 & 0.1997 & 0.203 \\
$\mathrm{Fe}$ & 0.8834 & 0.0792 & 0.2768 \\
$\mathrm{Ni}$ & 0.8929 & 0.3231 & 0.0015 \\
$\mathrm{Cu}$ & 0.9423 & -0.0077 & 0.2811 \\
$\mathrm{Zn}$ & 0.9715 & 0.1256 & 0.1389 \\
$\mathrm{As}$ & 0.6599 & 0.5904 & -0.1872 \\
$\mathrm{Rb}$ & 0.8862 & -0.04 & 0.29 \\
$\mathrm{Sr}$ & 0.0402 & 0.147 & 0.9675 \\
$\mathrm{Ba}$ & 0.0761 & 0.9325 & 0.2809 \\
$\mathrm{~Pb}$ & 0.4065 & 0.5243 & 0.6689 \\
$\mathrm{Bi}$ & 0.9163 & 0.287 & 0.1481 \\
\hline
\end{tabular}

(b)

\begin{tabular}{lccc}
\hline & \multicolumn{3}{c}{ Variance explained by each factor } \\
Factor & Variance & Percent & Cum. percent \\
\hline Factor 1 & 9.5731 & 56.313 & 56.313 \\
Factor 2 & 2.9045 & 17.085 & 73.398 \\
Factor 3 & 2.8535 & 16.785 & 90.183 \\
\hline
\end{tabular}

for elements lighter than K. Quantification of the detected low $\mathrm{Z}$ elements is not reported because our measurements were performed in air, and vacuum conditions are recommended in this case [30]. Results of quantitative analysis of rice and rice husk samples are reported in Table 5.
Elemental composition of rice husk and rice is similar for all the studied samples, even if $\mathrm{Ca}, \mathrm{Ti}, \mathrm{Mn}, \mathrm{Fe}$, and $\mathrm{Pb}$ are higher in $\mathrm{RH}$ with respect to rice. The concentration of metals in the two matrices is usually correlated. In the samples from Korba the highest concentrations of Ti, Fe, and $\mathrm{Zn}$ were detected in sample 3 for both the analyzed matrices (3R_K and 3RH_K) and the highest concentration of $\mathrm{Ca}$ and $\mathrm{Mn}$ in sample 1 (1R_K and $\left.1 \mathrm{RH}_{-} \mathrm{K}\right)$. In the samples from Raipur the highest concentrations of Fe and $\mathrm{Zn}$ are found in sample 3 (3R_R and 3RH_R), while the highest content of Mn was in sample 4 (4R_R and 4RH_R). Rice husk samples of Korba contain $\mathrm{Cr}$ that is not detected in rice, while $\mathrm{Cr}$ is present in both the matrices collected in Raipur, with the usual correlation. This can be due to the higher concentration of Cr in Raipur than Korba soils. The correlation observed for the other elements is not present in the case of $\mathrm{Pb}$. Indeed, the highest value of $\mathrm{Pb}$ for rice husk samples is present in sample $5 \mathrm{RH} \_\mathrm{K}$, while the highest value of $\mathrm{Pb}$ for rice is present in sample 2R_K. A similar behavior is observed for $\mathrm{Ca}$ and $\mathrm{Ti}$ in the samples from Raipur.

Descriptive statistics of elemental content in rice and rice husk samples is reported in Table 6. The comparison of heavy metals concentration in rice grain from the two studied areas shows no significant differences among $\mathrm{K}, \mathrm{Ca}, \mathrm{Ti}, \mathrm{Ni}, \mathrm{Cu}$, and $\mathrm{Zn}$. Other elements such as $\mathrm{Cr}, \mathrm{Fe}$, and $\mathrm{Pb}$ are higher in Raipur samples, while $\mathrm{Mn}$ and $\mathrm{Rb}$ are higher in Korba samples. Concentration of heavy metals detected in rice samples decreases in the following order: $\mathrm{Mn}>\mathrm{Zn}>\mathrm{Cu}>\mathrm{Ni}>$ $\mathrm{Pb}>\mathrm{Cr}$.

Metal uptake is higher for plants germinated in soils enriched with metals from anthropogenic factors. Therefore, bioaccumulation ability of plants is one of the most critical problems faced in agriculture and environmental studies. Transfer factor (TF) is an indicator of the plant species ability or tendency to uptake a certain element from the soil [31]. TF is obtained by dividing the element concentration in the plant by its concentration in soil, according to (1) where $C_{\mathrm{p}}$ is the metal concentration in plant and $C_{\mathrm{s}}$ is the metal 


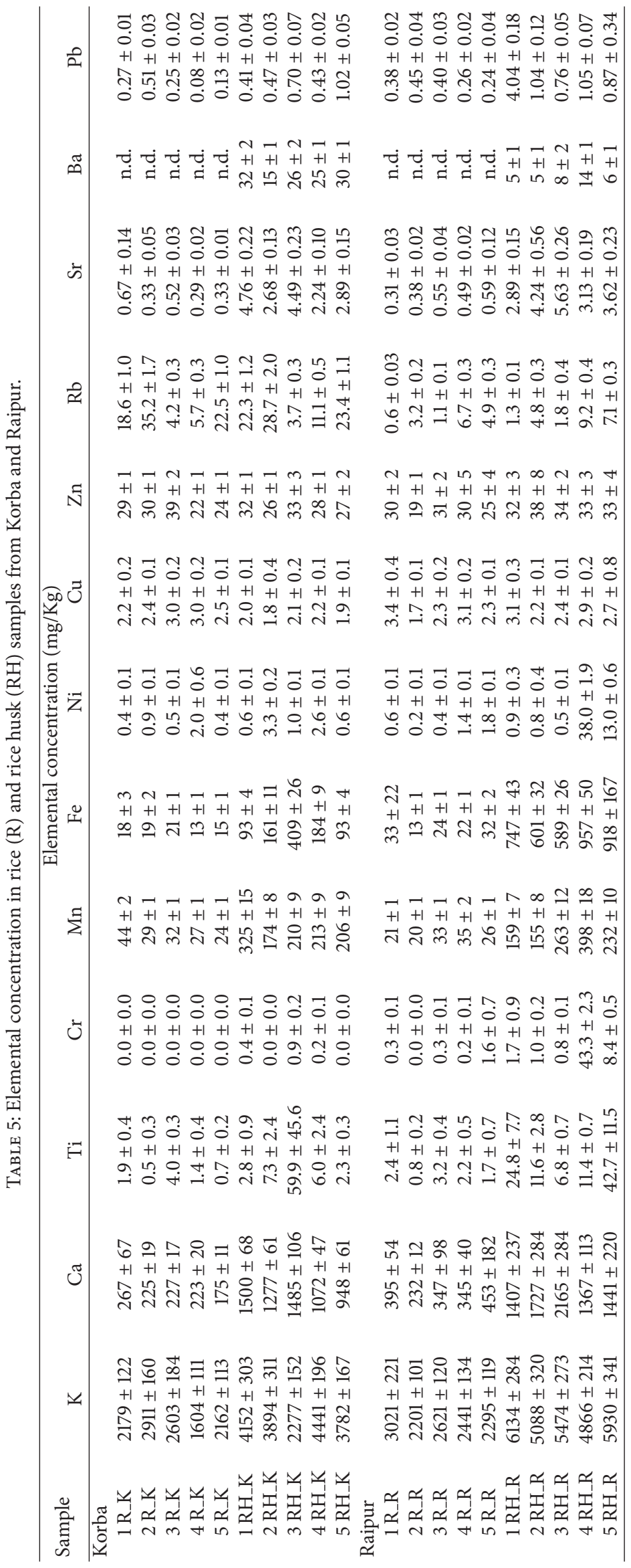


TABLE 6: Descriptive statistics results of elemental chemical analysis for rice and rice husk from Korba and Raipur.

\begin{tabular}{|c|c|c|c|c|c|c|c|c|c|c|c|c|c|}
\hline & $\mathrm{K}$ & $\mathrm{Ca}$ & $\mathrm{Ti}$ & $\mathrm{Cr}$ & $\mathrm{Mn}$ & $\mathrm{Fe}$ & $\mathrm{Ni}$ & $\mathrm{Cu}$ & $\mathrm{Zn}$ & $\mathrm{Rb}$ & $\mathrm{Sr}$ & $\mathrm{Ba}$ & $\mathrm{Pb}$ \\
\hline \multicolumn{14}{|l|}{ Korba } \\
\hline \multicolumn{14}{|l|}{ Rice } \\
\hline Mean & 2291.61 & 223.52 & 1.71 & 0.00 & 31.19 & 17.25 & 0.85 & 2.61 & 28.92 & 17.24 & 0.43 & n.d. & 0.25 \\
\hline $\mathrm{SD}$ & 495.62 & 32.67 & 1.41 & 0.00 & 7.63 & 3.14 & 0.67 & 0.36 & 6.64 & 12.79 & 0.16 & n.d. & 0.17 \\
\hline Min & 1603.61 & 175.06 & 0.47 & 0.00 & 23.97 & 13.20 & 0.39 & 2.22 & 22.18 & 4.18 & 0.29 & n.d. & 0.08 \\
\hline Max & 2910.56 & 267.13 & 4.02 & 0.00 & 43.67 & 20.86 & 2.01 & 3.00 & 39.09 & 35.19 & 0.67 & n.d. & 0.51 \\
\hline \multicolumn{14}{|l|}{$\mathrm{RH}$} \\
\hline Mean & 3709.19 & 1256.24 & 15.67 & 0.32 & 225.62 & 188.03 & 1.62 & 2.01 & 29.49 & 17.85 & 3.41 & 25.62 & 0.61 \\
\hline SD & 839.90 & 245.48 & 24.83 & 0.09 & 57.67 & 130.03 & 1.22 & 0.13 & 3.22 & 10.18 & 1.14 & 6.45 & 0.26 \\
\hline Min & 2277.06 & 947.76 & 2.30 & 0.00 & 174.33 & 92.74 & 0.62 & 1.85 & 25.87 & 3.69 & 2.24 & 15.40 & 0.41 \\
\hline Max & 4440.80 & 1499.97 & 59.92 & 0.90 & 325.00 & 408.97 & 3.25 & 2.17 & 33.31 & 28.69 & 4.76 & 31.96 & 1.02 \\
\hline \multicolumn{14}{|l|}{ Raipur } \\
\hline \multicolumn{14}{|l|}{ Rice } \\
\hline Mean & 2515.78 & 354.45 & 2.09 & 0.47 & 26.85 & 24.73 & 0.88 & 2.56 & 27.07 & 3.29 & 0.46 & n.d. & 0.34 \\
\hline $\mathrm{SD}$ & 323.75 & 81.34 & 0.88 & 0.11 & 6.91 & 8.24 & 0.66 & 0.71 & 5.09 & 2.56 & 0.12 & n.d. & 0.09 \\
\hline Min & 2200.82 & 231.92 & 0.84 & 0.00 & 19.66 & 12.67 & 0.22 & 1.66 & 19.09 & 0.58 & 0.31 & n.d. & 0.24 \\
\hline Max & 3020.55 & 452.90 & 3.24 & 1.60 & 34.50 & 32.61 & 1.77 & 3.44 & 31.36 & 6.69 & 0.59 & n.d. & 0.45 \\
\hline \multicolumn{14}{|l|}{$\mathrm{RH}$} \\
\hline Mean & 5498.53 & 1621.25 & 19.48 & 11.02 & 241.33 & 762.37 & 10.64 & 2.66 & 34.12 & 4.84 & 3.90 & 7.67 & 1.55 \\
\hline SD & 538.45 & 335.42 & 14.63 & 18.30 & 99.08 & 172.01 & 6.21 & 0.35 & 2.13 & 3.39 & 1.09 & 3.86 & 1.39 \\
\hline Min & 4866.02 & 1366.79 & 6.83 & 0.80 & 155.14 & 588.74 & 0.52 & 2.19 & 32.18 & 1.31 & 2.89 & 4.67 & 0.76 \\
\hline Max & 6134.38 & 2165.07 & 42.73 & 43.26 & 397.79 & 956.78 & 38.05 & 3.08 & 37.65 & 9.21 & 5.63 & 14.17 & 4.04 \\
\hline
\end{tabular}

concentration in soil. The variation observed in TFs for the same species may be due to several factors such as the age of the plant, the tissue, and the environment in which the plant is grown. It was demonstrated that the absorption of minerals and their distribution in the plant hang on the bioavailability of the minerals in soil, root structure, and shoot system [32]. Moreover, the bioavailability of elements from soil to plants is determined by other factors including $\mathrm{pH}$, redox conditions, speciation, soil texture and mineralogy, organic matter content, and the presence of competing ions.

TFs calculated for rice and $\mathrm{RH}$ using the average values of elemental concentration in rice, $\mathrm{RH}$, and soils of Korba and Raipur are shown in Figure 4. In our study, TFs for RH were always higher than rice samples for both the studied areas. TFs of $\mathrm{K}, \mathrm{Mn}, \mathrm{Cu}, \mathrm{Zn}, \mathrm{Rb}$, and $\mathrm{Ba}$ are higher in Korba samples compared to those of Raipur. Elements such as $\mathrm{Ca}$ and $\mathrm{Cr}$ show TFs higher in Raipur samples, while $\mathrm{Ti}, \mathrm{Fe}, \mathrm{Ni}$, and $\mathrm{Pb}$ were in the same range. Our results clearly show that the bioaccumulation is higher in $\mathrm{RH}$ than in rice:

$$
\mathrm{TF}=\frac{C_{\mathrm{p}}}{C_{\mathrm{s}}} .
$$

A comparison with the literature data [33] for the content of As, $\mathrm{Ba}, \mathrm{Cu}, \mathrm{Pb}, \mathrm{Ni}, \mathrm{Mn}$, and $\mathrm{Cr}$ in rice is reported in Table 7. The average values, calculated as the arithmetic mean, for Korba and Raipur are reported separately. The literature reports that geometric means (GM) illustrate more exact distribution of the element concentrations in rice samples, but comparison with many other studies is difficult due to the lack of information on GM [33]. As and $\mathrm{Ba}$ are not present

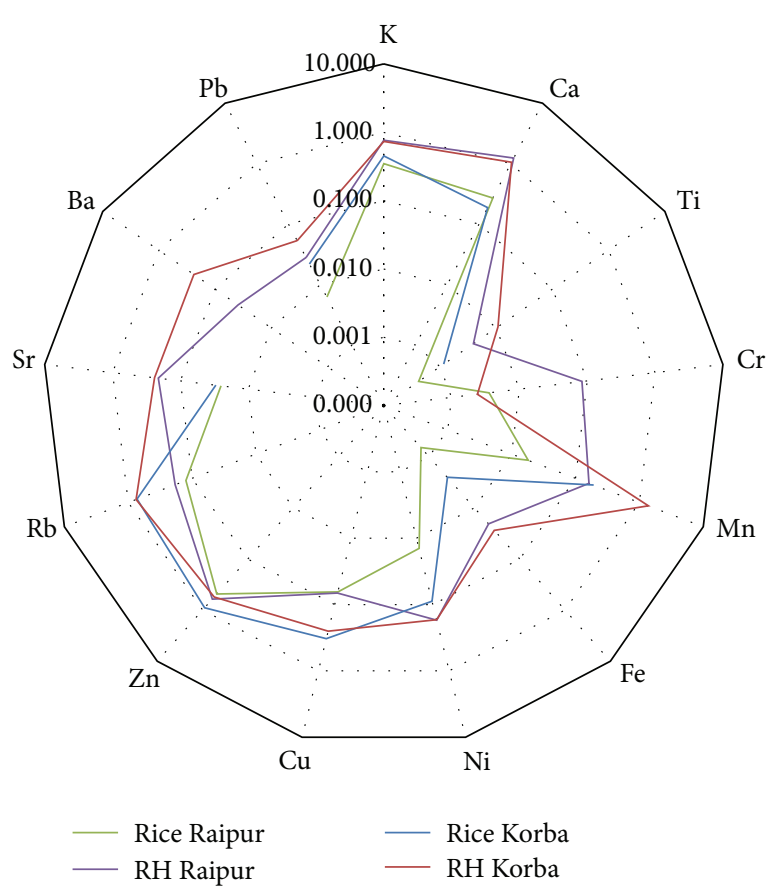

FIGURE 4: Transfer factors calculated for rice and rice husk samples with respect to soil samples from Korba and Raipur.

in our samples. Our values of $\mathrm{Cu}$ and $\mathrm{Ni}$ are aligned mainly with those from Vietnam. The concentrations of $\mathrm{Pb}$ and $\mathrm{Mn}$ are aligned, respectively, with commercial rice from China 
TABLE 7: Concentration of hazardous elements in rice samples reported in different literature studies: (a) arithmetic means; (b) arithmetic standard deviations; (c) [34]; (d) [35]; and (e) [36].

\begin{tabular}{|c|c|c|c|c|c|c|}
\hline Element & Area & $N$ & $\mathrm{AM}(\mathrm{a})$ & $\mathrm{ASD}(\mathrm{b})$ & MIN & MAX \\
\hline \multirow{7}{*}{$\mathrm{Cu}$} & Taizhou & 13 & 4260 & 826 & 3037 & 5184 \\
\hline & Commercial rice, China & 5 & 3326 & 774 & 2812 & 4478 \\
\hline & Vietnam $(c)$ & 31 & 2600 & & 1100 & 5800 \\
\hline & Bangladesh (d) & & - & - & - & - \\
\hline & Hangzhou (e) & & - & - & - & - \\
\hline & Raipur & 5 & 2560 & 710 & 1662 & 3438 \\
\hline & Korba & 5 & 2610 & 360 & 2222 & 2995 \\
\hline \multirow{7}{*}{$\mathrm{Pb}$} & Taizhou & 13 & 2042 & 2070 & 256 & 2602 \\
\hline & Commercial rice, China & 4 & 356 & 267 & 167 & 745 \\
\hline & Vietnam $(c)$ & & - & - & - & - \\
\hline & Bangladesh (d) & 3 & 2370.0 & 1980.0 & 2010.0 & 2400.0 \\
\hline & Hangzhou (e) & 5 & 131 & 103 & 45 & 308 \\
\hline & Raipur & 5 & 340 & 90 & 235 & 452 \\
\hline & Korba & 5 & 250 & 170 & 78 & 514 \\
\hline \multirow{7}{*}{$\mathrm{Ni}$} & Taizhou & 13 & 761 & 391 & 339 & 1134 \\
\hline & Commercial rice, China & 4 & 476 & 276 & 201 & 818 \\
\hline & Vietnam (c) & 31 & 869 & & $<100$ & 2022 \\
\hline & Bangladesh (d) & & - & - & - & - \\
\hline & Hangzhou (e) & & - & - & - & - \\
\hline & Raipur & 5 & 880 & 660 & 216 & 1770 \\
\hline & Korba & 5 & 850 & 670 & 387 & 2009 \\
\hline \multirow{7}{*}{$\mathrm{Mn}$} & Taizhou & 13 & 28640 & 5570 & 21977 & 37490 \\
\hline & Commercial rice, China & 4 & 9363 & 3288 & 5804 & 12708 \\
\hline & Vietnam $(c)$ & 31 & 9900 & & 5900 & 16300 \\
\hline & Bangladesh $(\mathrm{d})$ & & - & - & - & - \\
\hline & Hangzhou (e) & & - & - & - & - \\
\hline & Raipur & 5 & 2685 & 6910 & 19700 & 34500 \\
\hline & Korba & 5 & 31200 & 7600 & 24000 & 43700 \\
\hline \multirow{7}{*}{$\mathrm{Cr}$} & Taizhou & 13 & 107 & 83 & 6 & 279 \\
\hline & Commercial rice, China & 4 & 199 & 157 & 62 & 424 \\
\hline & Vietnam $(c)$ & & - & - & - & - \\
\hline & Bangladesh (d) & 3 & 740 & 340 & 650 & 830 \\
\hline & Hangzhou (e) & & - & - & - & - \\
\hline & Raipur & 5 & 470 & 110 & 0 & 1600 \\
\hline & Korba & 5 & n.d. & n.d. & n.d. & n.d. \\
\hline
\end{tabular}

and Taizhou. The content of $\mathrm{Cr}$ in the samples of Raipur is exceptionally high.

Despite all the reported data of metal content in rice, according to the national standard for safety milled rice criteria [37] (NY5115-2002), the maximum allowable concentrations (MAC) of As and $\mathrm{Pb}$ are 0.50 and $0.20 \mu \mathrm{g} / \mathrm{g}$, respectively. Moreover, the World Health Organization (WHO) provides $0.20 \mathrm{mg} / \mathrm{Kg}$ as the safe limit for $\mathrm{Pb}$ in rice [38], but it does not report any limit for other analyzed metals. In the present study, $\mathrm{Pb}$ concentration is much higher than the reported limit in many samples both from Raipur and Korba, even if the average value is aligned with that of WHO. Even it is known as a toxic element, $\mathrm{Cr}$ safe limit from WHO/FAO is not determined. Since rice is the common food for the Asian continent and especially in China, the MAC criteria determine the same limit for some metals such as $\mathrm{Cu} 10 \mathrm{mg} / \mathrm{Kg}$, $\mathrm{Zn} 50 \mathrm{mg} / \mathrm{Kg}$, Cr $1 \mathrm{mg} / \mathrm{Kg}$, and $\mathrm{Pb}$ as that decided by $\mathrm{WHO}$ [39].

Statistical analysis does not show any significant difference between rice and rice husk samples of the two areas of interest.

Figure 5 shows the concentration of selected elements in all samples, classified by species: soil, rice husk, and rice. This figure highlights the possible transfer and/or accumulation of elements from soil into the other two matrices. In some cases, rice husk seems to act as a barrier for some heavy metals such 

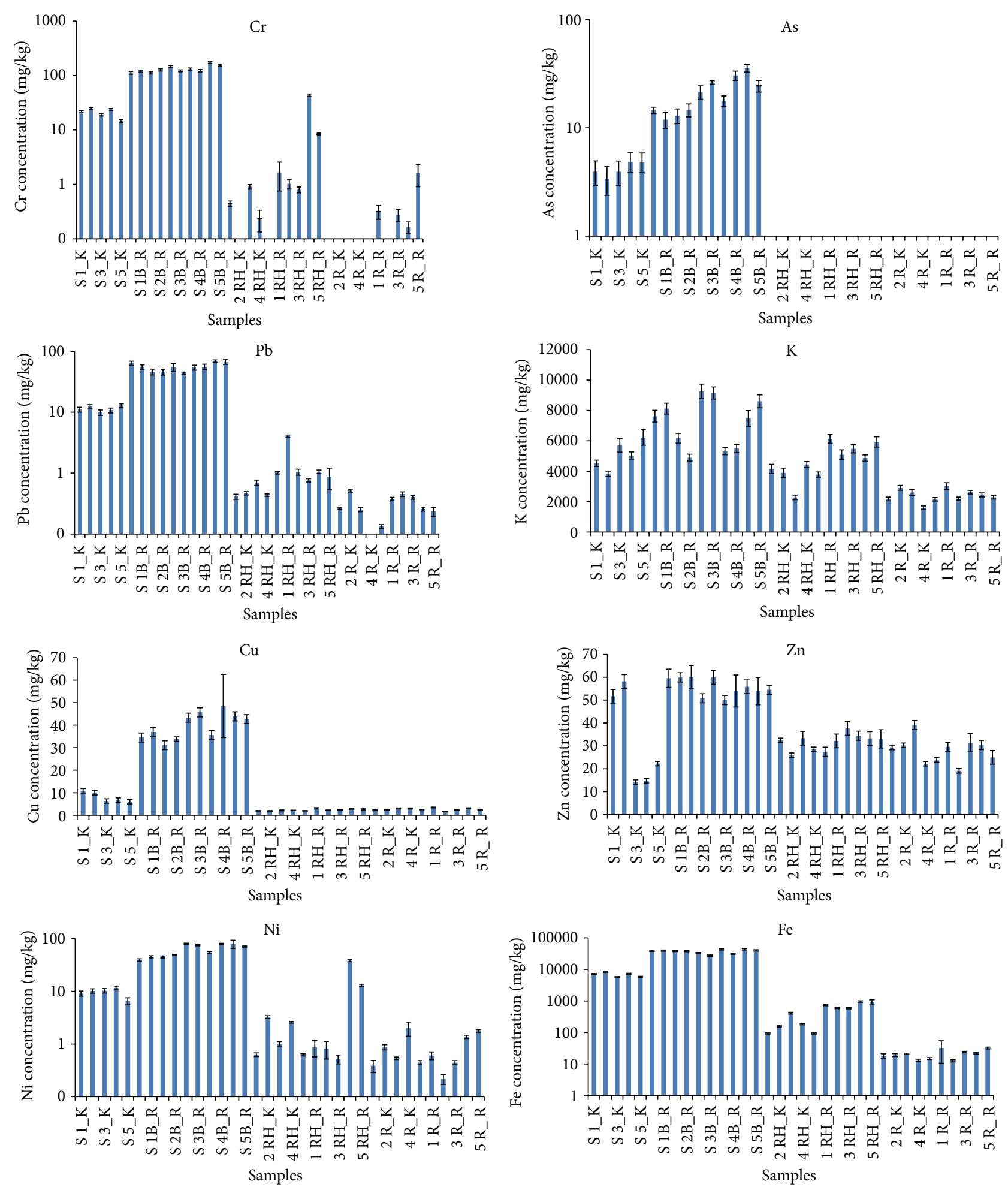

FIGURE 5: Concentration of elements in soil, rice husk, and rice samples from Korba and Raipur.

as $\mathrm{Cr}, \mathrm{K}, \mathrm{Fe}$, and $\mathrm{Pb}$. The possible barrier role of rice husk is interesting, and it can be hypothesized also for $\mathrm{Mn}, \mathrm{Ba}$, and Sr. Unfortunately, it is not clear in the case of $\mathrm{Cu}, \mathrm{Ni}, \mathrm{Zn}, \mathrm{Rb}$, $\mathrm{Bi}, \mathrm{Ti}$, and $\mathrm{V}$.

\section{Conclusions}

This work reports the chemical composition study of soils, rice, and rice husk, from Korba and Raipur (India), by means 
of TXRF. Results show some metals uptake from soil to rice, in particular $\mathrm{Pb}$ and $\mathrm{Cr}$ from the Raipur region. The novelty of this study is the chemical characterization of rice, made in parallel with the analysis of soils and corresponding rice husk. A detailed analysis of all the data shows that rice husk accumulates more heavy metals than rice, suggesting a possible barrier effect of the husk. Despite that, dedicated studies should be done to verify the clear role of husk and other parameters, such as rice species, soils characteristics $(\mathrm{pH}$, clay content, and organic matter), and other variables. Based on the extremely interesting results obtained in this study, some approaches may be developed to promote low metals accumulation in rice.

\section{Conflict of Interests}

The authors declare that there is no conflict of interests regarding the publication of this paper.

\section{Acknowledgments}

This study was supported by LIFE+, the financial instrument of the European Community to support environmental projects (LIFE+ 2011 Project ENV/IT/000256). The authors are grateful to Directorate-General Environment, European Commission for inclusion of COSMOS-RICE Project in Science for Environment Policy, Information Service (see http://ec.europa.eu/environment/integration/research/newsalert/pdf/383na2_en.pdf). The authors acknowledge Professor Patel, School of Studies in Chemistry, Pt. Ravishankar Shukla University, Raipur, India, for the support in samples collection.

\section{References}

[1] C. Huamain, Z. Chunrong, T. Cong, and Z. Yongguan, "Heavy metal pollution in soils in China: status and countermeasures," Ambio, vol. 28, no. 2, pp. 130-134, 1999.

[2] M. E. Watanabe, "Phytoremediation on the brink of commercialization," Environmental Science \& Technology, vol. 31, pp. 82A-187A, 1997.

[3] S. Uchida, K. Tagami, and N. Ishikawa, "Concentration, soil-toplant transfer factor and soil-soil solution distribution coefficient of selenium in the surface environment -9106," in Proceedings of the Symposium on Waste Management (WM '09), pp. 1-5, Phoenix, Ariz, USA, March 2009.

[4] X. F. Hu, Y. Jiang, Y. Shu, X. Hu, L. Liu, and F. Luo, "Effects of mining wastewater discharges on heavy metal pollution and soil enzyme activity of the paddy fields," Journal of Geochemical Exploration, vol. 147, part B, pp. 139-150, 2014.

[5] A. Sekara, M. Poniedziałek, J. Ciura, and E. Jedrszczyk, "Cadmium and lead accumulation and distribution in the organs of nine crops: implications for phytoremediation," Polish Journal of Environmental Studies, vol. 14, no. 4, pp. 509-516, 2005.

[6] R. Stone, "Food safety-arsenic and paddy rice: a neglected cancer risk?" Science, vol. 321, no. 5886, pp. 184-185, 2008.

[7] Committee for the Common Organisation of Agricultural Markets 11, 2014, http://ec.europa.eu/agriculture/cereals/presentations/rice/market-situation_en.pdf.
[8] K. R. Dikshit and J. E. Schwartzberg, "India: iI paese," in Enciclopedia Britannica, pp. 9-10, 2007.

[9] K. M. Omatola and A. D. Onojah, "Elemental analysis of rice husk ash using X-ray fluorescence technique," International Journal of Physical Sciences, vol. 4, no. 4, pp. 189-193, 2009.

[10] L. Sun and K. Gong, "Silicon-based materials from rice husks and their applications," Industrial and Engineering Chemistry Research, vol. 40, no. 25, pp. 5861-5877, 2001.

[11] S. Sugita, "On the economical production of large quantities of highly reactive rice husk ash," in Proceedings of the International Symposium on Innovative World of Concrete (ICI-IWC '93), pp. 2, 3-71, 1993.

[12] I. R. Shaikh and A. A. Shaikh, "Utilization of wheat husk ash as silica source for the synthesis of MCM-41 type mesoporous silicates: a sustainable approach towards valorization of the agricultural waste stream," Research Journal of Chemical Sciences, vol. 3, pp. 66-72, 2013.

[13] K. M. Omatola and A. D. Onojah, "Rice husk as a potential source of high technological raw materials: a review," Journal of Polymer Science Innovation, vol. 4, pp. 30-35, 2012.

[14] A. Bosio, N. Rodella, A. Gianoncelli et al., "A new method to inertize incinerator toxic fly ash with silica from rice husk ash," Environmental Chemistry Letters, vol. 11, no. 4, pp. 329-333, 2013.

[15] A. Bosio, A. Zacco, L. Borgese et al., "A sustainable technology for $\mathrm{Pb}$ and $\mathrm{Zn}$ stabilization based on the use of only waste materials: a green chemistry approach to avoid chemicals and promote $\mathrm{CO}_{2}$ sequestration," Chemical Engineering Journal, vol. 253, pp. 377-384, 2014.

[16] A. Taylor, S. Branch, M. P. Day, M. Patriarca, and M. White, "Atomic spectrometry update. Clinical and biological materials, foods and beverages," Journal of Analytical Atomic Spectrometry, vol. 24, no. 4, pp. 535-579, 2009.

[17] K. S. Patel, K. Shrivas, P. Hoffmann, and N. Jakubowski, "A survey of lead pollution in Chhattisgarh State, central India," Environmental Geochemistry and Health, vol. 28, no. 1-2, pp. 1117, 2006.

[18] K. S. Patel, K. Shrivas, R. Brandt, N. Jakubowski, W. Corns, and P. Hoffmann, "Arsenic contamination in water, soil, sediment and rice of central India," Environmental Geochemistry and Health, vol. 27, no. 2, pp. 131-145, 2005.

[19] B. Giri, K. S. Patel, N. K. Jaiswal et al., "Composition and sources of organic tracers in aerosol particles of industrial central India," Atmospheric Research, vol. 120-121, pp. 312-324, 2013.

[20] http://www.epa.gov/osw/hazard/testmethods/sw846/pdfs/ 3050b.pdf.

[21] L. Borgese, A. Zacco, E. Bontempi et al., "Total reflection of xray fluorescence (TXRF): a mature technique for environmental chemical nanoscale metrology," Measurement Science and Technology, vol. 20, no. 8, Article ID 084027, 2009.

[22] F. Bilo, L. Borgese, D. Cazzago et al., "TXRF analysis of soils and sediments to assess environmental contamination," Environmental Science and Pollution Research, vol. 21, no. 23, pp. 13208-13214, 2014.

[23] Esdat 2000, Dutch Target and Intervention Values, The new Dutch list, 2000, http://www.esdat.net/.

[24] A. Kabata-Pendias, "Environmental biogeochemistry-outline of the development," Przeglad Geologiczny, vol. 49, no. 10, pp. 957-959, 2001.

[25] S. Srinivasa Gowd, M. Ramakrishna Reddy, and P. K. Govil, "Assessment of heavy metal contamination in soils at Jajmau 
(Kanpur) and Unnao industrial areas of the Ganga Plain, Uttar Pradesh, India," Journal of Hazardous Materials, vol. 174, no. 1-3, pp. 113-121, 2010.

[26] K. S. Patel, A. Verma, N. K. Jaiswal et al., "Arsenic concentration in soil, rice and straw in central India," in Proceedings of the 4th International Congress on Arsenic in the Environment, pp. 508509, July 2012.

[27] A. Kabata-Pendias, Trace Elements in Soils and Plants, Technology \& Engineering, CRC Press, 3rd edition, 2000.

[28] A. D. Jacobson and J. D. Blum, "Ca/Sr and 87Sr/86Sr geochemistry of disseminated calcite in Himalayan silicate rocks from Nanga Parbat: influence on river-water chemistry," Geology, vol. 28, no. 5, pp. 463-466, 2000.

[29] Y. N. Vodyanitskii, "Criteria of the technogenic nature of heavy metals and metalloids in soils: a review of publications," Eurasian Soil Science, vol. 42, no. 9, pp. 1053-1061, 2009.

[30] H. Hoefler, C. Streli, P. Wobrauschek, M. Óvári, and G. Záray, "Analysis of low Z elements in various environmental samples with total reflection X-ray fluorescence (TXRF) spectrometry," Spectrochimica Acta Part B: Atomic Spectroscopy, vol. 61, no. 1011, pp. 1135-1140, 2006.

[31] K. K. Taha, I. M. Shmou, H. M. Osman, and M. H. Shayoub, "Soil-plant transfer and accumulation factors for trace elements at the Blue and White Niles," Journal of Applied and Industrial Sciences, vol. 1, pp. 97-102, 2013.

[32] H. Papaefthymiou, G. Papatheodorou, A. Moustakli, D. Christodoulou, and M. Geraga, "Natural radionuclides and ${ }^{137} \mathrm{Cs}$ distributions and their relationship with sedimentological processes in Patras Harbour, Greece," Journal of Environmental Radioactivity, vol. 94, no. 2, pp. 55-74, 2007.

[33] J. Fu, Q. Zhou, J. Liu et al., "High levels of heavy metals in rice (Oryza sativa L.) from a typical E-waste recycling area in southeast China and its potential risk to human health," Chemosphere, vol. 71, no. 7, pp. 1269-1275, 2008.

[34] T. D. Phuong, P. Van Chuong, D. T. Khiem, and S. Kokot, "Elemental content of Vietnamese rice. Part 1. Sampling, analysis and comparison with previous studies," Analyst, vol. 124, no. 4, pp. 553-560, 1999.

[35] S. W. Al Rmalli, P. I. Haris, C. F. Harrington, and M. Ayub, "A survey of arsenic in foodstuffs on sale in the United Kingdom and imported from Bangladesh," Science of the Total Environment, vol. 337, no. 1-3, pp. 23-30, 2005.

[36] C. Fangmin, Z. Ningchun, X. Haiming et al., "Cadmium and lead contamination in japonica rice grains and its variation among the different locations in southeast China," Science of the Total Environment, vol. 359, no. 1-3, pp. 156-166, 2006.

[37] National Programme on Safety Food, Safety Milled Rice Criteria of PR China (NY5115-2002), China Ministry of Agriculture, Beijing, China, 2002.

[38] FAO/WHO, Codex Alimentarius General Standards for Contaminants and Toxins in Food. Schedule1. Maximum and Guideline Levels for Contaminants and Toxins in Food, Joint FAO/WHO Food Standards Programme, Reference CX/FAC 02/16, Codex Committee, Rotterdam, The Netherlands, 2002.

[39] The Ministry of Health of China, GB 2762-2012: Standards for Chinese Food Sanitation, The Ministry of Health of China, 2012. 

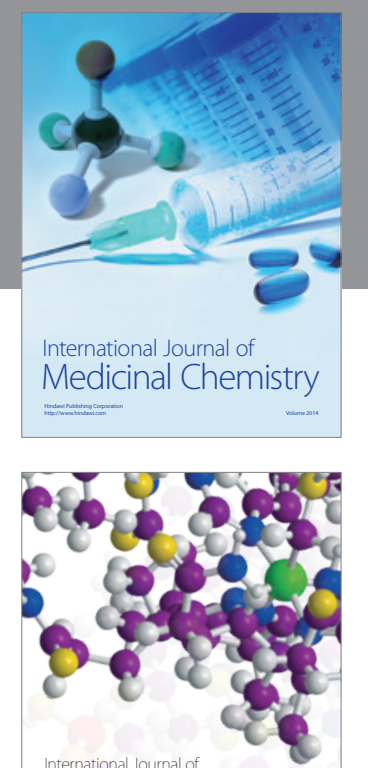

\section{Carbohydrate} Chemistry

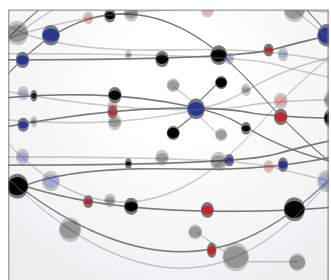

The Scientific World Journal
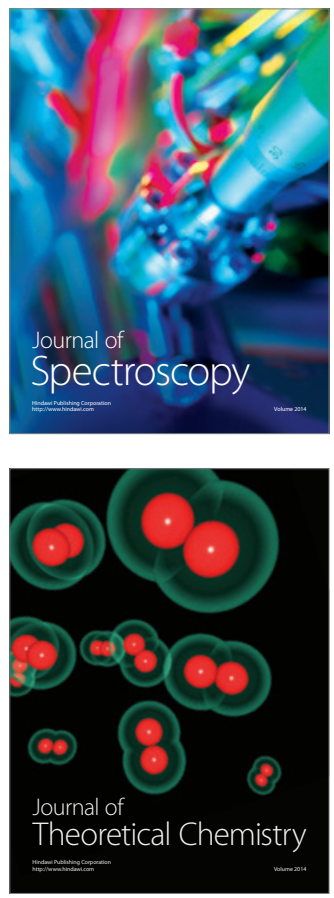
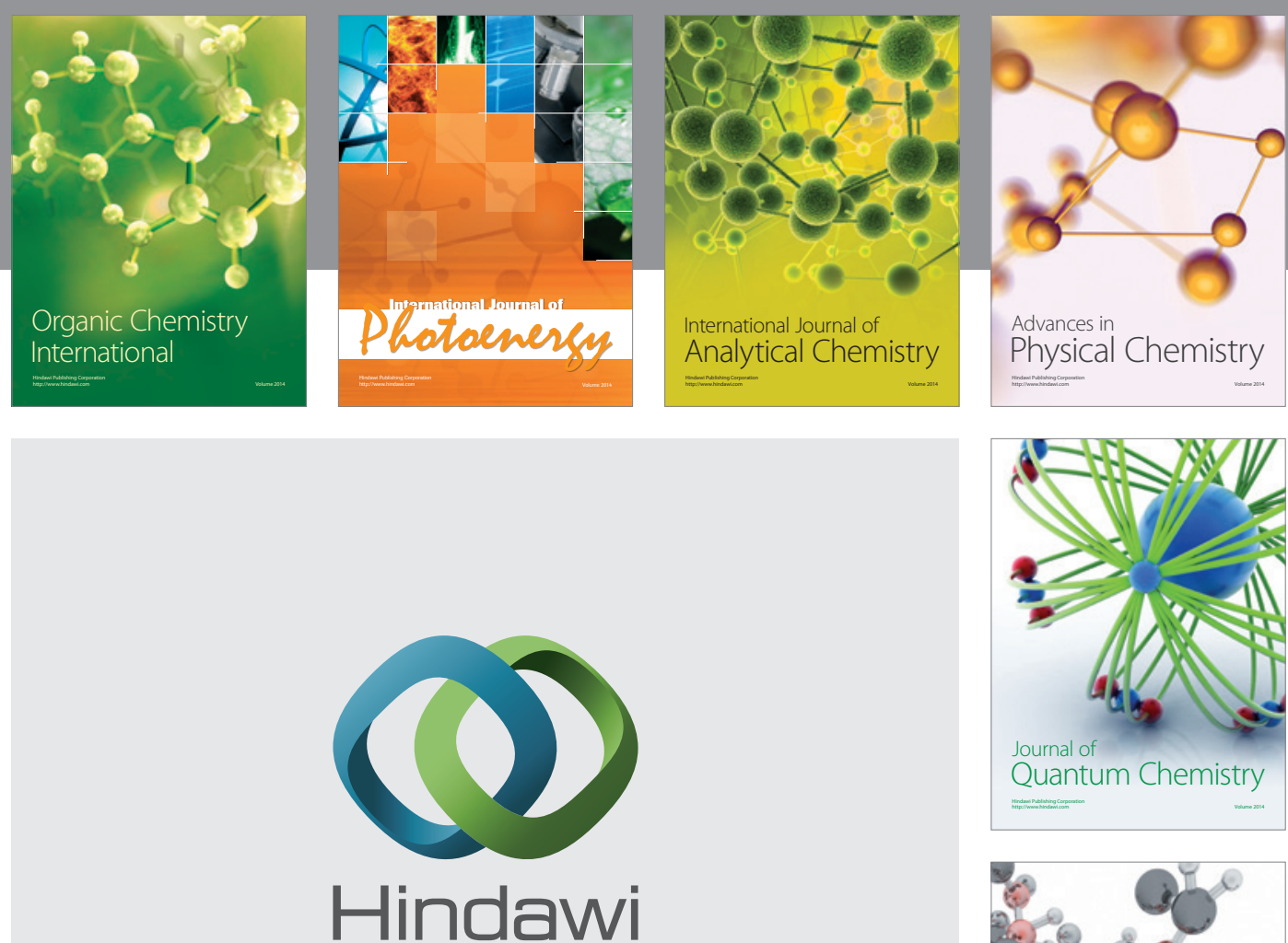

Submit your manuscripts at

http://www.hindawi.com

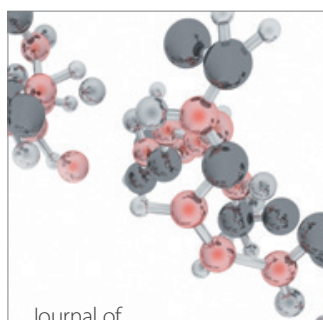

Analytical Methods

in Chemistry

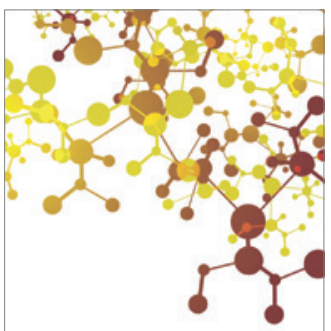

Journal of

Applied Chemistry

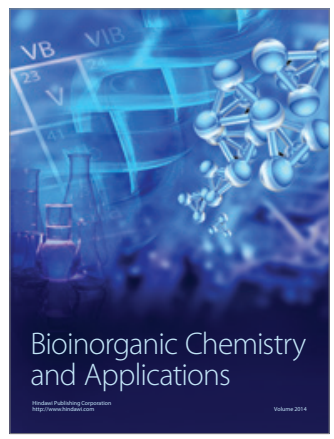

Inorganic Chemistry
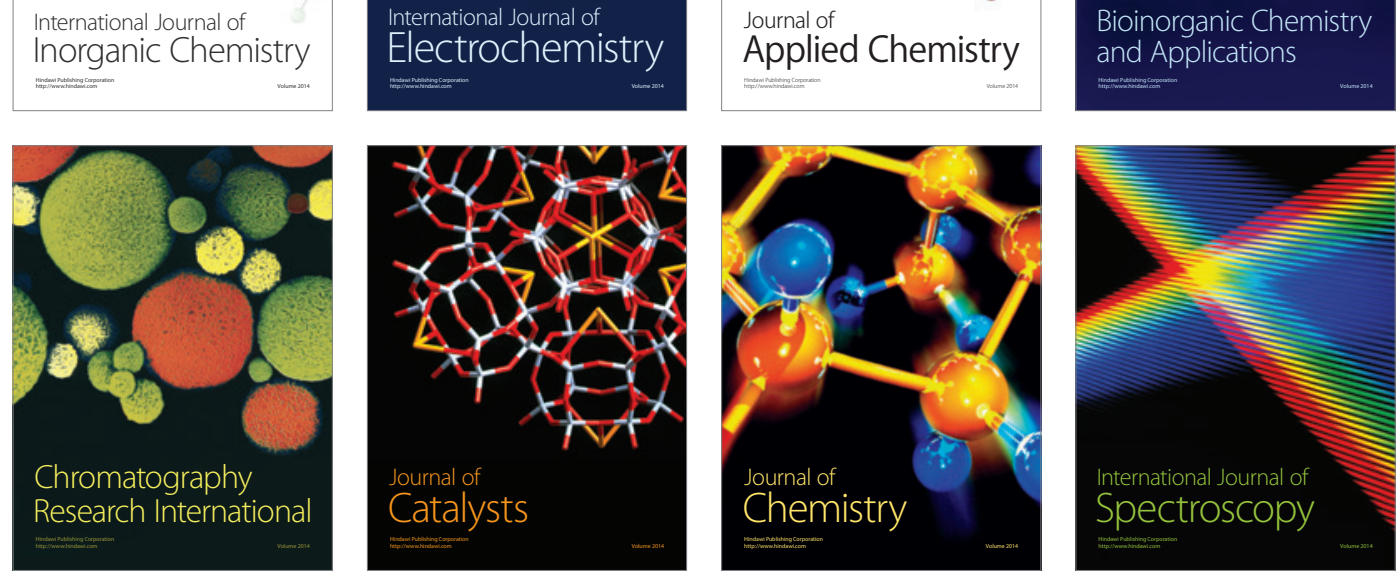